\title{
Biological nitrification inhibition (BNI) in Brachiaria pastures: A novel strategy to improve eco-efficiency of crop-livestock systems and to mitigate climate change
}

\author{
DANILO E. MORETA ${ }^{1}$, JACOBO ARANGO ${ }^{1}$, MAURICIO SOTELO ${ }^{1}$, DANIEL VERGARA ${ }^{1}$, \\ ALVARO RINCÓN ${ }^{2}$, MANABU ISHITANI ${ }^{1}$, ARACELY CASTRO ${ }^{1}$, JOHN MILES $^{1}$, MICHAEL PETERS $^{1}$, \\ JOE TOHME ${ }^{1}$, GUNTUR V. SUBBARAO ${ }^{3}$ AND IDUPULAPATI M. RAO ${ }^{1}$ \\ ${ }^{1}$ Centro Internacional de Agricultura Tropical (CIAT), Cali, Colombia. www.ciat.cgiar.org \\ ${ }^{2}$ Corporación Colombiana de Investigación Agropecuaria (Corpoica), C.I. La Libertad, Villavicencio, Colombia. \\ www.corpoica.org.co

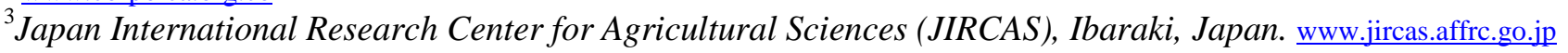

Keywords: Ammonium-oxidizing microorganisms, nitrous oxide emissions, nitrogen use efficiency, genetic variation.

\section{Introduction}

Up to $70 \%$ of the nitrogen $(\mathrm{N})$ fertilizers applied to agricultural systems is lost due to nitrification and denitrification. Nitrification is a microbiological process that generates nitrate $\left(\mathrm{NO}_{3}{ }^{-}\right)$and promotes the loss of $\mathrm{N}$ fertilizers by leaching and denitrification. Nitrification and denitrification are the only known biological processes that generate nitrous oxide $\left(\mathrm{N}_{2} \mathrm{O}\right)$, a powerful greenhouse gas contributing to global warming. There is an urgent need to suppress nitrification processes in soil to improve $\mathrm{N}$ recovery and $\mathrm{N}$ use efficiency (NUE) of agricultural systems and to mitigate climate change (Subbarao et al. 2012). Certain Brachiaria grasses (B. humidicola) can suppress soil nitrification by releasing biological nitrification inhibitors (BNIs) from roots, thereby reducing $\mathrm{N}_{2} \mathrm{O}$ emissions. This phenomenon, termed biological nitrification inhibition (BNI), has been the subject of recent research to characterize and validate the concept under field conditions (Subbarao et al. 2009).

Advances on 3 aspects of BNI research are reported here: (1) gene quantification of soil nitrifying microorganisms to determine BNI activity in B. humidicola; (2) screening of $B$. humidicola breeding materials to identify hybrids with contrasting levels of BNI; and (3) quantification of the BNI residual effect from $B$. humidicola on $\mathrm{N}$ recovery and agronomic NUE of a subsequent maize crop.

Correspondence: Idupulapati M. Rao, Centro Internacional de Agricultura Tropical (CIAT), Apartado Aéreo 6713, Cali, Colombia.

Email: i.rao@cgiar.org

\section{Methods}

Gene quantification of soil nitrifying microorganisms to determine BNI activity in $\mathrm{B}$. humidicola

A proof of concept work was designed to monitor the dynamics of nitrification in soils as influenced by Brachiaria spp. with differential BNI capacities (Subbarao et al. 2009). A soybean crop and bare soil, which lack such BNI capacity, were used as controls. Ammonium sulfate was applied to each plot. Copy numbers of amoA genes of ammonia-oxidizing bacteria (AOB) and archaea (AOA) were determined through Real-Time PCR to quantify the impact of inhibitory effects from $B$. humidicola under field conditions at 1 day after the ammonium sulfate application.

Screening of B. humidicola breeding materials to identify hybrids with contrasting levels of BNI

A set of apomictic $B$. humidicola hybrids were screened by determining nitrification rates in soil samples taken from unreplicated field plots established for seed production. Four CIAT accessions were used as controls for BNI activity.

Quantification of the BNI residual effect from

B. humidicola on $N$ recovery and NUE of a subsequent maize crop

A 1-ha field was selected from each of 3 contrasting land uses: a 15-year-old pasture of B. humidicola CIAT 679 (cv. Tully) with accumulated inhibitory effect in soil (i.e. high BNIs in soil); a nearby agricultural field (in which a 
crop rotation of maize and soybean was practiced for 4 years) with low BNIs in soil; and a native savanna field with moderate level of BNIs in soil. Hybrid maize (Pioneer 30K73) was sown on 17 July 2012 at all 3 field sites. Nitrogen fertilizer was applied at 3 rates $(60,120$ and $240 \mathrm{~kg} \mathrm{~N} / \mathrm{ha}$ ) at each site. Grain yield and agronomic NUE were determined to assess the BNI residual effect on subsequent maize cultivation.

\section{Results}

Molecular data confirmed that B. humidicola accession CIAT 16888 has the capacity to inhibit soil nitrification (BNI activity). Rhizosphere soil from $B$. humidicola CIAT 16888 plots exhibited a lower gene copy number of AOB and AOA amoA genes than the controls (soybean and bare soil) and the other tropical grasses (Figure 1). Different values of nitrification rates observed in field plots of $B$. humidicola breeding materials suggested genetic variation for BNI and contributed to identification of hybrids with contrasting BNI capacities (Figure 2 ). The higher grain yields of maize observed from B. humidicola pasture land use were associated with greater values of agronomic NUE, particularly at lower rates of $\mathrm{N}$ applied $(60 \mathrm{~kg} / \mathrm{ha})$. This observation indicates the importance of accumulated BNIs from this pasture over time in improving the agronomic NUE of maize crop (Figure 3).

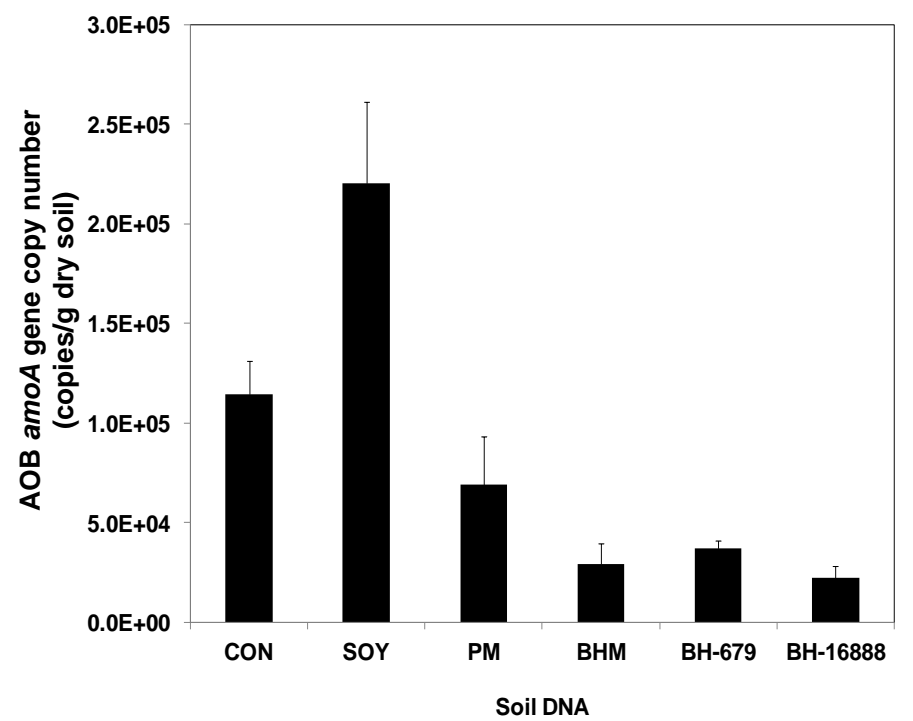

\section{Conclusion}

BNI activity in Brachiaria humidicola plots was confirmed by observing a lower copy number of amoA genes from bacterial and archaeal populations compared with soybean and bare soil plots. The wide variation of nitrification rates observed in a set of apomictic $B$. humidicola hybrids contributed to the identification of hybrids with contrasting BNI capacity. Accumulation of BNIs in soil of a long-term B. humidicola pasture improved grain yield and agronomic NUE of the subsequent maize crop.

\section{References}

Subbarao GV; Nakahara K; Hurtado MP; Ono H; Moreta DE; Salcedo AF; Yoshihashi AT; Ishikawa T; Ishitani M; Ohnishi-Kameyama M; Yoshida M; Rondón M; Rao IM; Lascano CE; Berry WL; Ito O. 2009. Evidence for biological nitrification inhibition in Brachiaria pastures. Proceedings of the National Academy of Sciences of the United States of America 106:17302-17307.

Subbarao GV; Sahrawat KL; Nakahara K; Ishikawa T; Kishii M; Rao IM; Hash CT; George TS; Srinivasa Rao P; Nardi P; Bonnett D; Berry W; Suenaga K; Lata JC. 2012. Biological nitrification inhibition - A novel strategy to regulate nitrification in agricultural systems. Advances in Agronomy 114:249-302.

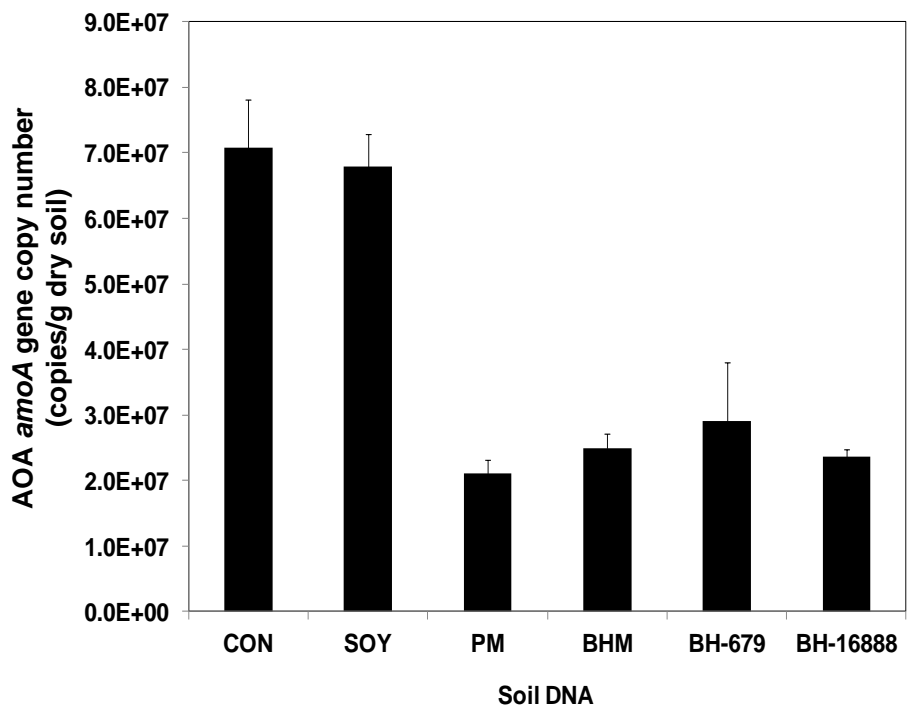

Figure 1. Gene copy numbers of ammonia-oxidizing bacteria (AOB) amoA gene (left), and ammonia-oxidizing archaea (AOA) amoA gene (right) at 1 day after ammonium sulfate application. $\mathrm{CON}=$ control (bare soil); SOY = soybean; $\mathrm{PM}=$ Panicum maximum; $\mathrm{BHM}=$ Brachiaria hybrid cv. Mulato; BH-679 = B. humidicola CIAT 679 (standard cv. Tully); BH-16888 = B. humidicola CIAT 16888 (a high-BNI capacity germplasm accession). Gene copy number was expressed as copy number per $\mathrm{g}$ of dry soil. Values are mean \pm s.e. from 3 replications. 
4.5

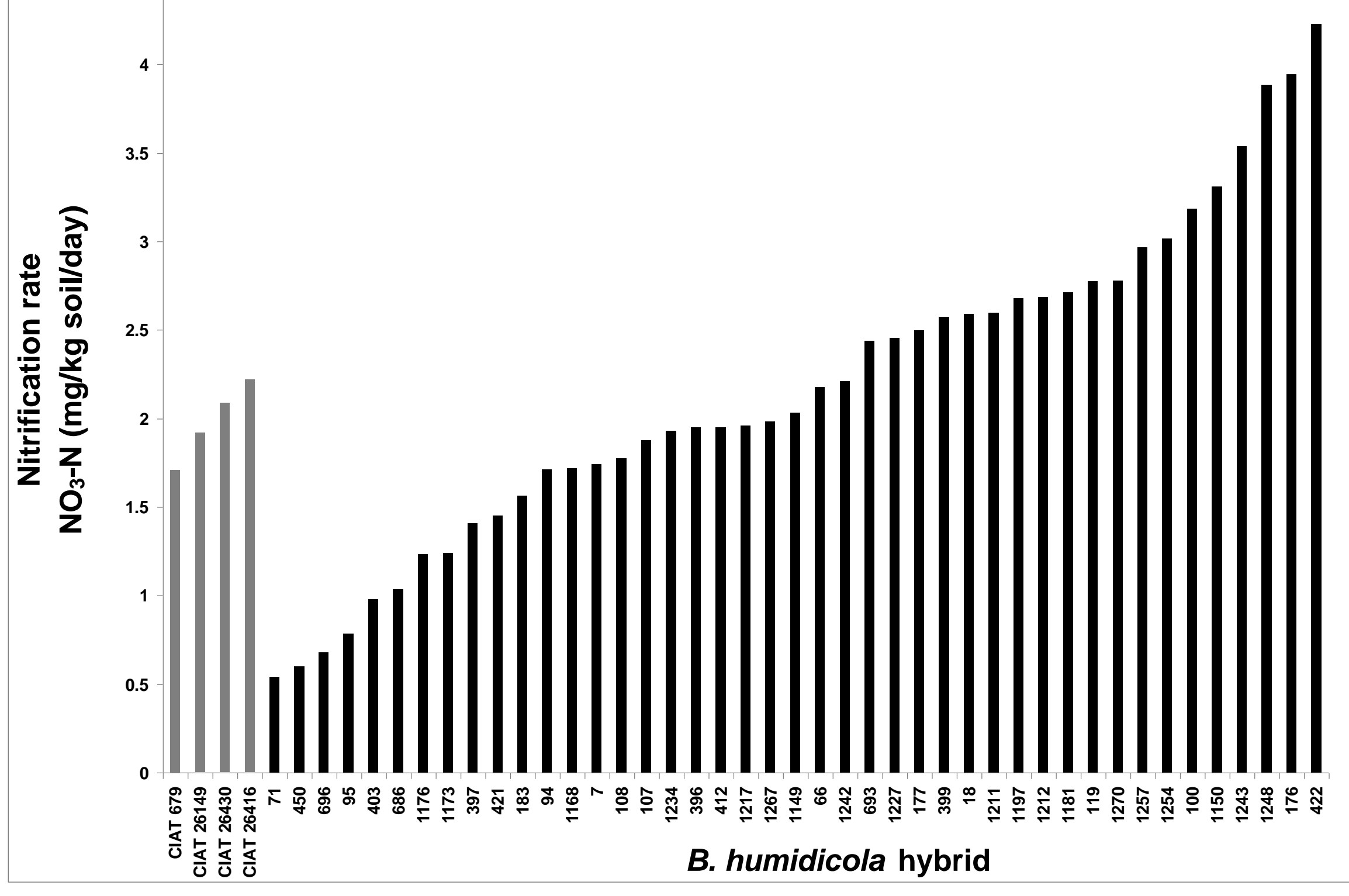

Figure 2. Genotypic differences in nitrification rates - expressed as $\mathrm{NO}_{3}-\mathrm{N}(\mathrm{mg} / \mathrm{kg}$ soil/d) in field plots of $B$. humidicola hybrids. Gray bars represent $B$. humidicola CIAT accessions used as controls. 


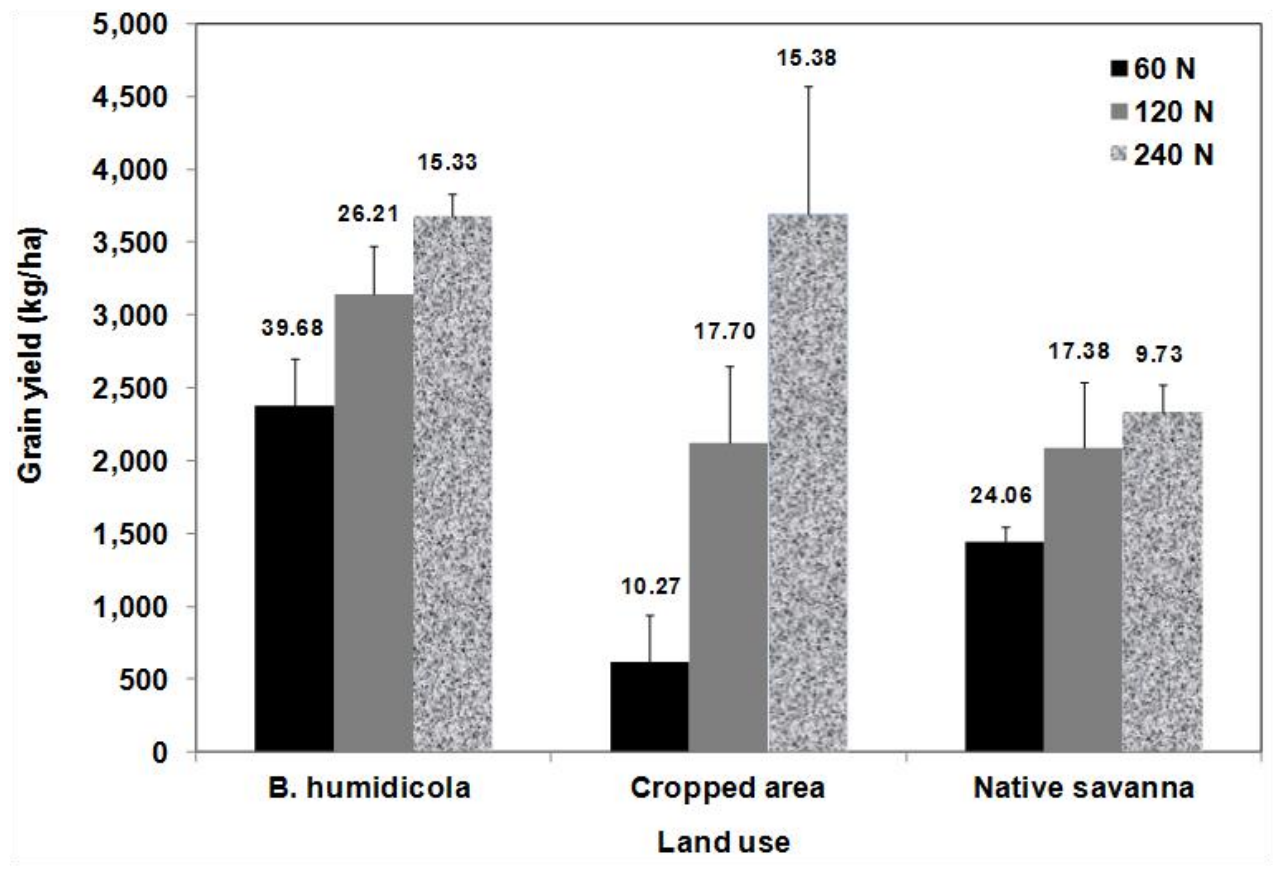

Figure 3. Grain yield (kg/ha) from maize plots fertilized with 60,120 and $240 \mathrm{~kg} \mathrm{~N} / \mathrm{ha}$, on areas with different previous land uses (15-yr-old B. humidicola pasture; 4 years maize-soybean rotations; and native savanna). Agronomic nitrogen use efficiency (kg grain yield/kg $\mathrm{N}$ applied) values are shown above the s.e. bars. Values are means \pm s.e. from 3 replications.

\section{(c) (i) (2) (2)}

Tropical Grasslands-Forrajes Tropicales is an open-access journal published by Centro Internacional de Agricultura Tropical (CIAT). This work is licensed under a Creative Commons Attribution-NonCommercial-ShareAlike 3.0 Unported License. To view a copy of this license, visit http://creativecommons.org/licenses/by-nc-sa/3.0/ 
Moreta DE; Arango J; Sotelo M; Vergara D; Rincón A; Ishitani M; Castro A; Miles J; Peters M; Tohme J; Subbarao GV; Rao IM. 2014. Biological nitrification inhibition (BNI) in Brachiaria pastures: A novel strategy to improve eco-efficiency of crop-livestock systems and to mitigate climate change. Tropical Grasslands - Forrajes Tropicales 2:88-91.

DOI: $\underline{10.17138 / \mathrm{TGFT}(2) 88-91}$

This paper was presented at the $22^{\text {nd }}$ International Grassland Congress, Sydney, Australia, 15-19 September 2013. Its publication in Tropical Grasslands - Forrajes Tropicales is the result of a co-publication agreement with the IGC Continuing Committee. Except for adjustments to the journal's style and format, the text is essentially the same as that published in: Michalk LD; Millar GD; Badgery WB; Broadfoot KM, eds. 2013. Revitalising Grasslands to Sustain our Communities. Proceedings of the $22^{\text {nd }}$ International Grassland Congress, Sydney, Australia, 2013. New South Wales Department of Primary Industries, Orange, NSW, Australia. p. 980-981. 